\title{
Ion Budai-Deleanu, Opere. Tiganiada. Trei viteji. Scrieri lingvistice. Scrieri istorice. Traduceri, editie îngrijită, cronologie, note și comentarii, glosar și repere critice de Gh. Chivu şi Eugen Pavel, studiu introductiv de E. Simion, Academia Română, Editura Fundației Naționale pentru Știință și Artă, București, 2011, 1354 p.
}

\author{
Maricica Munteanu* \\ Faculty of Letters, "Alexandru Ioan Cuza" University, Bd. Carol I 11, 700506 Iași, Romania
}

The issue of Budai-Deleanu's Opere, edited by Gh. Chivu and Eugen Pavel, sets out the attempt to familiarize the public with an author that has been forgotten and filed away for the reason of being vetust (and hence removed from the handbooks), an author that suscitates the interest of a few specialists only, preoccupied with old literature.

The present edition is composed of four parts, complying with the chronological principle: Scrieri beletristice [Fictional Writings], Scrieri lingvistice [Linguistic Writings], Scrieri istorice [Historical Writings] and Traduceri [Translations]. It also includes an introduction written by Eugen Simion, chronology and critical apparatus selected by Eugen Pavel, a glossary, notes and textual commentaries by Gh. Chivu (for the linguistic and historical writings, and the translations) and Eugen Pavel (for the fictional writings and the translation from Metastasio). The notes and textual commentaries are attached at the end of the volume, and not included in the text, to avoid the overcrowding with information and to make the text accessible to the common reader, "a person of culture in the general sense of the word", as the editors postulate in Notă asupra ediției [Note on the Edition]. For the same reasons a selection has been conducted regarding the writings of a wider expanse, aiming to satisfy the potential interest of the reader, on the one hand, and, on the other hand, to avoid the redundancy by omitting some ideas and arguments that would not have brought more information to the reader. A selection was also carried out with regard to the translations, the editors seeking to transcribe the relevant passages for configuring the mentality specific to that era and to encapsulate the author's "cultural attitude" towards the introduction of neologisms in the Romanian scientific and legal domains. Therefore, the volume presents itself as an attempt to embody a certain period, with its mental reflexes and socio-political frames.

For realizing this critical edition, the authors have used, on the one hand, the previous critical editions, and, on the other hand, the original manuscripts, which can be found mostly at the Romanian Academy Library from Bucharest, and also at the Central University Library of Cluj-Napoca. A brief editing history of Ion Budai-Deleanu's work, after 1869 , when Gh. Asachi hands them in to the Central Library of Bucharest (transferred to the Romanian Academy Library in 1903), is included in the chronology realized by Eugen Pavel. Tiganiada's first version was published in $1875-1877$ by Teodor Codrescu, in the revue "Buciumul Românesc" from Iași, and only in 1925 the edition attended by Gh. Cardas, issued the definitive version from 1800-1812. Along with the late reception, Budai-Deleanu's work has been deformed by a series of non-critical editions that brutally modified the text by eliding entire passages or changing some words (for example, the editions attended by Virgil Onițiu, Mihail I. Pricopie, G. Adamescu or Ion Pillat). The editions considered to be "truly scientific" and analyzed at large in Notă asupra editiiei are realized by Jacques Byck and Florea Fugariu. The linguistic and historical writings appeared much later than the fictional ones. The editors mention the volumes Scrieri lingvistice [Linguistic Writings], edited by Mirela Teodorescu and Ion Gheție, Scrieri inedite [Unpublished Writings] issued by Iosif Pervain, and a critical edition of the study named De originibus populorum Transylvanie, published by Ladislau Gyémánt. Furthermore, amendments and corrections are made to the previous editions both in Notă asupra ediției, as well in the notes

*Email address:mari.munteanu@ymail.com. 
at the end of the volume. For example, in the case of Tiganiada, there are compared, in Note și comentarii [Notes and Comments], the editions of Gh. Cardaş, J. Byck and Florea Fugariu, registering and correcting the wrong lections by consulting the poem's two versions from the original manuscripts. The analysis of this editing history highlights the faulty reception of Budai-Deleanu's work. While the poems Tiganiada and Trei viteji have aroused the interest of some editors (although the first critical editions of the two poems, those of J. Byck, appear only in 1953 and 1956, respectively), the linguistic and historical writings, as well as the translations, have been left in the shadows (Mirela Teodorescu and Ion Gheție edition is published in 1970, L. Gyémánt edition, in 1991, and some fragments from the translated texts, in 1983). However, none of the quoted editions gathers texts from the various areas in which BudaiDeleanu activated. The present edition has the advantage to present not only the work of an author, but also his personality, a man of culture's profile: an erudite illuminist nature, writer, theologian, jurist, linguist, counselor at the Lvov Court of Appeal, initiator in linguistic and literary areas by introducing neologisms in Romanian language with the help of translations, and by connecting the European values to the national realities, advocate of the democratization and popularization of culture in a humanist way, for the elevation of the masses.

Another issue that challenged the editors was to establish the optimal version, the period, the authorship and the autonomy of the texts. Controversial was the option regarding Tiganiada, as the poem has been transmitted in two autograph manuscripts: the version $\mathrm{A}$, kept in ms. rom. $2634 \mathrm{BAR}$, and the version $B$, kept in ms. rom. 2429 BAR. It has been considered, sometimes, throughout the process of editing, that the version $B$ precedes the version $A$ that was seen as the final one, reshaped and improved (in Aron Densusianu's opinion) or that the Becicherec episode, reproduced in the poem Trei viteji and absent from the version $B$, is not an autonomous text, but a late insertion in a definitive version, namely the version A (Perpessicius' interpretation). The current edition reproduces the version $\mathrm{B}$ as the final one that follows the version $\mathrm{A}$. There are also three broadsheets among the translations (Rinduială pentru vînătoare, Așezămînt pentru țăranii din Bucovina și Instrucții pentru pașapoarte și emigrația din Bucov- ina), that are the result of Budai-Deleanu's activity as the counselor of Lvov Court of Appeal with the purpose to introduce Austrian legislation in the territory of Bucovina. These translations do not belong with certainty to the author. The argument of the authorship has been demonstrated by Lucia Protopopescu, and detailed later by N.A. Ursu, both of the researchers consulting the Viennese archives, and relating some linguistic and style features to the author's geographic area and to his particular style from other autograph texts. For every text of the four parts of the volume the editors have attempted to reconstruct, in addition to the technical data of the editing process, the approximate year of the writings and a minimal context (especially for the historical and translated texts) in order to reflect some cultural and mentality aspects of the transitory period between the $18^{\text {th }}$ and $19^{\text {th }}$ centuries. One of the difficulties in the editing process of Budai-Deleanu's work was to transliterate the texts written with Cyrillic letters and the fragments based on etymological spelling. To resolve the impasse, the editors have applied the principle of interpretative transliteration, respecting the literary norms of the period, the geographic area embodied by the text, and the particular style of the author ("his image regarding the elevate aspect of our literary language"). Therefore, without brutally interfering in the text, the editors try to preserve the language of the respective times, managing to create a connective and dynamic relation between the linguistic structures and the historical, cultural and mental frames of a certain period. For a better understanding of the text, a glossary containing approximately 1500 words has been attached, which resonates with the editors' intension of making the volume accessible to the common reader, who is "more interested in the content and less so in the form".

The edition contains a critical apparatus that wraps the different angles of Budai-Deleanu's reception. The most of these critical opinions approach the fictional writings, particularly T,iganiada, the interest for the rest of the writings being quite limited. In the case of Tiganiada, the literary critique is especially concerned to track down the cultural and literary resources of the poem; sometimes it is outlined Budai-Deleanu's innovative sense of the language (for example, Ovid Densusianu); some other critics such as Nicolae Balotă or Eugen Negrici concentrates on the baroque features, while Mircea 
Anghelescu and Dumitru Popovici state out the fact that the author of Tiganiada is a romantic avant la lettre, and Nicolae Manolescu interprets the poem using the postmodernist techniques (irony, pastiche, plagiary, etc.). Of course, some of the interpretations tend to exaggerate, probably because of the several cultural complexes the Romanian writers seek to diminish by creating precedence (like the interpretation of Țiganiada from a postmodernist point of view). The introductive study written by Eugen Simion has the merit to correlate the author with his period. The critic also enumerates the literary sources of the poem (from Homer and Virgil to Dante and Milton); he accepts the existence of some "romantic" elements, but explains them through the influence of medieval literature and folklore (two areas treasured by the romantic thinking as well), and even comments on the so-called "metaliterature", but relates it to a didactic process. Eugen Simion describes Budai-Deleanu as an illuminist personality, with Occidental views, with interest in classic and modern literature, and in the national culture as well, a person with preoccupations for different domains from linguistics and literature to history and what is named today the psychology of nations (as Eugen Simion properly states out by giving the example of the study about Bucovina). Eugen Simion's introduction is convergent with the editors' purpose to capture the image of the author, and, at the same time, to embody a certain period of time with its historical, mental and socio-political conditions. Ion Budai-Deleanu's attempt of making a literary tradition by assimilating some Occidental cultural models, of innovating the Romanian language through the import of neologisms, his iterative affirmation of the Latin origin and territorial continuity of the Romanian nation, the insistence upon the necessity of a Romanian-German dictionary and his activity as lexicographer can be taken as several references for the study of history of literature, the history of mentalities or the intellectual history.

Ion Budai-Deleanu critical edition issued by Gh. Chivu and Eugen Pavel has the merit to bring together a diversity of the author's work, and correlating it to the expectations of a common reader, interested in the general image of the writer. Unfortunately, the extremely reduced printing number and the poor circulation of the edition (and this is the fate of all the books in the "Opere fundamentale" collection) come in contradiction with the editors' purpose. 